\title{
Abraham Kuyper en volksideologie onder die Afrikaners
}

Kobus Smit, Bloemfontein

\begin{abstract}
Kuyper and the ideology of the people amongst Afrikaners In recent times an unproblematic link was laid between Apartheid(or White) theology and the thought of Kuyper. In this paper attention is given to the discussions of AJ Botha, WJ de Gruchy, GJ Schutte and PJ Strauss. Although it is true that theologians from the Dutch Reformed Church were influenced by Kuyper, he can not be regarded as the scapegoat for Apartheid. In his political philosophy he was a confirmed proponent of individual freedom and rights. Apartheid as a nationalistic ideology is too complex a phenomenon to be viewed from just this one point of view. A radical democratisation of the South African community would rather reflect Kuyper's point of view.
\end{abstract}

\section{KUYPER EN SUID-AFRIKAANSE TEOLOGIE}

Gedurende 1987 is daar 'n Kuyper-dag deur die Teologiese Fakulteit van die Universiteit van die Oranje Vrystaat gereel, waaraan teoloè van die drie "Afrikaanse" kerke deelgeneem het. (Vergelyk Kleynhans, EPJ. (red). Abraham Kuyper na 150 jaar. UV Teologiese studies No. 2, 1989.) Ongelukkig reflekteer die gebeurtenis op sigself nie die voortgesette aktualiteit van Kuyper nie. Om die waarheid te sê, Kuyper is lank nie meer gewild in Gereformeerde geledere in Suid-Afrika nie. Deels moet dit gewyt word aan die assosiasie van apartheidsideologie met Kuyper se idee van skeppingsordeninge ('n idee wat ook verbind kan word met Hitler se regverdiging van sy uitwissingsoperasies).

\section{APARTHEID}

Dat die ideologiese gety in Suid-Afrika reeds gekeer het, blyk daaruit dat vir meer as 'n dekade geen teologiese werk verskyn het wat pretendeer om apartheid teologies te verdedig nie. Brosjures teen die progressiewe uitsprake in Kerk en Samelewing, die Nederduits Gereformeerde Kerk se verklaring van 1986, is onbeduidend.

Opvallend in resente teologiese publikasies van Nederduits Gereformeerde Kerk-teoloe, is 'n pynlike morele introspeksie. Die pynlikheid is juis te wyte aan die teologiese of kerklike regverdiging van apartheid. Hierdie vernuwing in die kerk kan niks anders wees as die werk van die Heilige Gees nie. Die verblydende is dat die proses van hervorming voltrek word ook op die gebied van politiek, ekonomie en selfs die kuns. Om 'n roman of drama of digbundel te vind wat nie die worsteling met die uitwasse van apartheid reflekteer nie, is haas onmoontlik. Engelse koerante blameer die regering vir alles. Afrikaanse koerante vra vrae 
en rasionaliseer. Ten spyte van 'n skynbare skaakmat-situasie wat grondwetlike hervorming betref, is daar weekliks veranderinge op te merk wat tweede- en derdevlakregering betref en ten opsigte van sosiale verkeer. Maar die kanker van die ideologie van etnisiteit is so diep gewortel in die gemeenskap dat dit geweldige inset kos om te verander wat verkeerd is. Kulturele chauvinisme en blatante selfsug is nog om elke hoek en draai te vind.

\section{IS KUYPER DIE SONDEBOK?}

Dit kom as 'n verrassing as mens die Gereformeerde Ekumeniese Sinode se RES Testimony on Human Rights lees, dat Kuyper se naam met instemming genoem word en dat die idee van skeppingsordeninge en die skeppingsopenbaring van God positief gebruik word. Wat Suid-Afrikaanse teoloe betref wat oor die leer van die skepping skryf, val dit op dat hulle Kuyper se naam nooit noem nie en die terminologie vermy. JJF Durand (Skepping, Mens, Voorsienigheid, 1982) en A König (Hy kan weer en meer, 1982) is voorbeelde hiervan. Durand (1982:194/7) bring skeppingsordeninge ter tafel slegs met verwysing na die Duitse teologie en die probleem van die Duitse Christene wat op grondslag van skeppingsteologie Duitsheid en Christenskap onlosmaaklik verknoop het. Hierteenoor sou die Belydende Kerk met die Barmenverklaring reageer. $\mathrm{Na}$ die behandeling van Brunner en Bonhoeffer noem Durand die twee hoofbesware teen volk as skeppingsordening. Die Nuwe Testament se Christusgetuienis relativeer die idee van die volk èn volkere ontstaan en verval in die historiese proses. Die geldigheid van hierdie kritiek is na die Tweede Wêreldoorlog in alle lande behalwe by 'n aantal Gereformeerde Suid-Afrikaanse teoloe aanvaar. Om apartheid teologies te regverdig was dit noodsaaklik om 'n saak daarvoor uit te maak dat 'n rasen volkeverskeidenheid 'n skeppings- of voorsienigheidsbeginsel is. Hiervoor was daar uiteindelik net twee tekste, naamlik Genesis $11: 1$ - 9 en Handelinge $17: 26$. Hierdie soort ordeningsteologie wat neerslag gevind het in Ras, volk en nasie en volkereverhoudinge in die lig van die Skrif (1974) het volgens hom geen lewensvatbaarheid nie. Die geskiedenis het dit reeds uitgewys. Durand vermeld glad nie die naam van Kuyper nie.

Beide Durand en König is aartsvyande van apartheid

Die evangeliese kerklui van Suid-Afrika het in hul beleidstuk Evangelical Witness (1986) Durand se ontleding beaam:

In South Africa for instance segregation of races is tied to this ordinance of creation as developed by the Afrikaans Reformed churches and enforced by law by the apartheid Regime.

Die stryd teen die vergrype van apartheid word met Durand, Konig en vele ander gedeel, maar waarom sou mens 'n hele teologiese tradisie ignoreer omdat dit op een punt verkeerd gebruik is? Moet (politieke?) geloof waardigheid gepaard gaan met die verloening van 'n teologiese én kulturele tradisie? Moet 'n mens nie ook hier die kaf van die koring skei eerder as om die kind met die badwater uit te gooi nie? Schrotenboer (1988 : 1) praat in Theological Forum van "lasting treasures" tussen "scholastic keepsakes"! 
Die positiewe bydrae wat Kuyper as joernalis, akademikus, staatsman en predikant-teoloog gelewer het en waarin die gereformeerde tradisie hom gevolg het, het veral te doen met die volgende sake:

- dat die Bybel normatief is vir ons ganse lewe, politiek ingeslote;

- dat die gesag van die staat van God kom en nié van die volk nie en dat dit sy taak is om publieke geregtigheid te bevorder as iets wat tot die sfeer van die algemene genade behoort;

- dat Bybelse norme geldig gemaak moet word in die publieke lewe deur die gewetensgetroue optrede van publieke ampsbekleërs en nié direk uit die Bybel of deur 'n teokratiese ingrype nie;

- dat die kerk as instelling van God wat die besondere genade bemiddel, rondom 'n belydenis georganiseer word;

- dat die sondeval ' $n$ realiteit is met gevolge vir individue en gemeenskappe (die staat onder andere);

- dat die roeping van die Christen skeppingswyd is en deur ' $n$ pluralistiese demokrasie uitgebou moet word:

- dat die skeppingsordeninge van God vir gemeenskappe die gedifferensieerde vryhede waarborg. (Vergelyk Langley, 1988:6.)

Of soos Skillen $(1988: 15,17)$ dit stel:

He began to understand in a profound way the meaning of the differentiation of modern society - a creational dynamic which is now global both in scope and complexity beyond our fathoming ... Apart from the Kuyper tradition. there is no major Christian view of life influential in the world today that call both for cultural engagement to reform all of society through the power of the gospel and for promotion of the differentiation of life spheres each in accord with its own God-ordained normative principles

Moet hierdie Kuyper nou verantwoordelikheid dra vir Wit Ideologie?

\section{DRIE MENINGS}

In hierdie artikel word die menings van drie skrywers gegee en opgeweeg teen Kuyper se eie siening oor die volk. Wat hierdie drie in gemeen het, is dat hulle nie veel aandag vra vir Kuyper se positiewe bydrae nie. Geen woord oor sy sosiale hervormingsprogram, uitbreiding van stemreg. anti-rewolusionére politiek, demokratisering van die Nederlandse gemeenskap, sy stryd teen die deformasie van die kerk of sy Christelike benadering van opvoeding en onderwys in 'n tyd toe Nederland prysgegee was aan die liberalisme nie.

\section{AJ BOTHA}

In sy doktorale proefskrif (1984) volg AJ Botha die lyn van M Elaine Botha (1982:47) wat meen dat die Kuypertradisie gelei het tot die identifikasie van kerk en volk in Suid-Afrika. Sy vind dat die "assimilering van nie-reformatoriese elemente" in Kuyper se teorie aanleiding gegee het tot negatiewe trekke in Afrikaner-nasionalisme. 'n Religieuse inhoud is toegevoeg tot die begrip "volk".

AJ Botha se uiteensetting van Kuyper se denke word hoofsaaklik begrens tot die Stone-lesings. Hy verwys na die gedagte van Christus se soewereiniteit oor die ganse skepping, na die alles-omvattende lewens- en wêreldbeskouing wat verband hou met Kuyper se ontleding van sfeersoewereiniteit en na die idee van skeppingsordeninge en pluralisme. 
Interessant genoeg sê hy op een plek (1984:180) dat "volk" nie deur Kuyper genoem word as hy die gesagsfere ontleed nie en net daarna (1984: 182) konstateer hy dat die "volk" by Kuyper die belangrikste van die skeppingsordeninge is.

Wie Kuyper se Stone-lesing oor Calvinisme en die politiek lees, staan verstom oor die beklemtoning van die individuele vryheid van die burger teenoor die verwerping van staatsabsolutisme. Die drievoudige staatsaak van straf, verdediging en ordening bly onderworpe aan die primaat van die reg (Kuyper, s.a.:57).

Oor staatsabsolutisme sê hy:

No man has the right to rule over another man. otherwise such a right necessarily, and immediately becomes the right of the strongest

Nor can a group of men, by contract, from their own right. compel to obey a fellow-man. What binding force is there for me in the allegation that ages ago one of my progenitors made a 'Contract Social', with other men of that time? As man I stand free and bold, over against the most powerful of my fellowmen ... in the sphere of the State I do not yield or bow down to anyone. who is man, as I am. (Kuyper, s.a.:50.)

Die direkte verantwoording aan die Koning van die eeue, verbied enige verknegting.

Calvinism protests against State-omnipotence; against the horrible conception that no right exists above and beyond existing laws; and against the pride of absolutism, which recognizes no constitutional rights, except as a result of princely favor. (Kuyper, s.a.:60).

Binne hierdie konteks speel die volk geen rol nie.

Botha (1984:262/4) het nagelaat om self Kuyper se idees oor "die volk" na te vors en maak noodgedwonge gebruik van die werk van andere Vir die doel van sy argument aanvaar hy dat Kuyper die hoofrede was vir die evolusie van 'n volksideologie in Suid-Afrika. Hy dui aan dat die Kuyper-teologie die meer pragmatiese teologiese stroming van Marais, Keet en Gerdener oorskadu het. Volgens hom vertoon Ras, volk en nasie (1974) nog die Kuyperiaanse idee van "die volk".

Hy blameer nie die "Doppers" met veral SJ du Toit as volgeling van Kuyper, vir wat verkeerd geloop het nie. Laasgenoemde het min invloed gehad in die Nederduits Gereformeerde Kerk. Die teoloe van die Nederduits Gereformeerde Kerk moet die verantwoordelikheid dra. Botha se sondebok is die beginsels van Kuyper se teorie!

\section{JW DE GRUCHY}

De Gruchy is veel versigtiger in sy benadering. In sy "Bonhoeffer and South Africa" (1984) dui hy aan dat die dominante tradisie in Suid-Afrika die Calvinistiese is, maar dat dit beskou word as deel van die probleem en nie van die oplossing nie. Hy verwys na die mening dat Kuyper verantwoordelik gehou word vir volksideologie.

Such a view is far too simplistic, though not without some truth . . (De Gruchy, 1984:105).

Die Calvinisme in Suid-Afrika vertoon verskeie strominge van die gereformeerde tradisie, waarvan die Kuyperiaanse een is. Hy beskou 'n studie van Kuyper se denke as 'n moontlike positiewe bydrae tot sosiale 
verandering. In hierdie verband verwys hy na Wolterstorff se Justice and Peace Embrace (1983).

Hy het geen twyfel daaroor dat Kuyper "has profoundly influenced Afrikaner Reformed thinking and action in South Africa," en dat Kuyper se idees "have been misused to support the ideology of apartheid and the policy of Separate Development." (De Gruchy. 1984:107.)

Sy analise dien om te demonstreer dat Neo-Calvinisme so verwring is in die proses dat die kritiese bydrae tot sosiale denke in Suid-Afrika grotendeels verlore gegaan het.

Dit moet by wyse van verduideliking toegevoeg word dat daar 'n groot verskil is tussen Kuyper en Afrikaner-teologie. Kuyper (s.a. 52/3) skryf byvoorbeeld oor gelykheid en demokrasie die volgende:

If Calvinism places our entire life immediately before God. then it follows that all men or women, rich or poor, weak or strong. dull or talented. as creatures of God. and as lost sinners, have no claim whatsoever to lord over one another. and that we stand as equals before God, and consequently as equals man to man .. . Calvinism was bound to find utterance in the democratic interpretation of life: to proclaim the liberty of nations; and not to rest until both politically and socially every man. simply because he is man, should be recognised, respected and dealt with as a creature created after the Divine likeness.

Sou mens hierdie gedagte kontrasteer met die volksideologie wat De Gruchy opmerk by N Diedericks, CR Kotze, FJM Potgieter en HG Stoker, is sy gevolgtrekking begryplik:

the end product was ... a contradiction of Kuyper's doctrine (De Gruchy, 1984:110).

Die Wet op Gemengde Huwelike kan diens doen as illustrasie. Kuyper formuleer die beginsel van soewereiniteit in eie kring ter wille van nieinmenging of maksimale realisering van vryhede. Die feit dat die Nederduits Gereformeerde Kerk die owerheid versoek het om so 'n wet op die wetboek te plaas, verkrag hierdie beginsel totaal. Dit is in wese ' $n$ dubbele gesagsvergryp.

'n Ander voorbeeld is die reg tot burgerlike ongehoorsaamheid wat nog altyd erken is in die gereformeerde teologie. Hieroor sê Kuyper (1931:168) die volgende:

In order that it may be able to rule men, the government must respect this deepest ethical power of human existence. A nation consisting of citizens whose consciences are bruised, is itself broken in its national strength.

Die hantering van die reg op nie-gewelddadige verset in Suid-Afrika laat veel te wense oor. Die uitgepluisde voorwaardelikheid vir burgerlike ongehoorsaamheid in Kerk en Samelewing, laat nie veel van 'n moontlike realisering van hierdie reg oorbly nie. (Vergelyk Smit, 1989:56.)

In 'n ander werk (The Church Struggle in South Africa, 1982) verwys De Gruchy na Kuyper se stryd om kerk en staat te skei en na sy invloed op Hollandse nasionalisme. Ook hierin bevestiğ hy dat Suid-Afrika ingrypend deur Kuyper beinvloed is en dat Kuyper via Dooyeweerd en Stoker uiteindelik die raamwerk bepaal het vir Afrikaner-nasionalisme en sy rassebeleid (De Gruchy. 1982:32/3). Hy haal in hierdie verband vir $\mathrm{T}$ Dunbar Moodie aan: 
For Stoker the people was a separate social sphere with its own structure and purpose, grounded in the ordinances of God's creation. (De Gruchy, 1984:32.)

Dit is interessant dat De Gruchy (1984:36) noem dat twee-derdes van die Suid-Afrikaanse bevolking in 1910 Engelssprekend was. Mens wil vra hoe dit dan moontlik is dat die Kuyperiaanse Calvinisme 'n skrale dertig jaar later op die punt staan om via die Afrikaanse Nederduits Gereformeerde Kerk totale leiding oor te neem in die Suid-Afrikaanse kultuur? (Vergelyk De Gruchy, 1982:7, 21, 32.)

\section{GJ SCHUTTE}

Die Nederlandse historikus, GJ Schutte publiseer in 1986 'n hoogswetenskaplike werk Nederland en de Afrikaner, adhesie en aversie Hierin probeer hy die wortels van die apartheidsideologie opspoor. Hy lewer kritiek op T Dunbar Moodie en I Hexham se analises. Hy het beswaar daarteen dat hulle apartheid analiseer as 'n geskiedenis van idees. 'n Ingewikkelde fenomeen soos (ideologiese) nasionalisme kan nie bloot vanuit een gesigspunt verklaar word nie. Dit gaan immers nie net om 'n ideologiese ideaal nie, al is die ideologiese komponente voluit aanwesig. Daar is ander faktore wat 'n volk kan mobiliseer, soos die verlies van mag, groot armoede en vernedering (Schutte. 1986:187). Hy verkies 'n sosiopolitieke benadering bo een wat eksklusief op ideologie konsentreer, omdat dit die moontlikheid bied om gelyke gewig toe te ken aan ideologiese, politieke en sosio-ekonomiese faktore. In hulle té "monolitiese" benadering sien hulle alleen 'n volgroeide nasionalisme sonder om die oorsake en funksie daarvan te verduidelik.

Alternatiewe idees en ideale onder Afrikaners is deur hulle uit die geskiedenis uit geskryf. Hy bevraagteken ook die gelykstelling van die negentiende eeuse nasionalisme met dié van die jare ná 1948. Ook hy verwerp die idee dat die "Doppers" verantwoordelik was vir die Afrikanermite.

Schutte lewer voldoende historiese bewysmateriaal dat Kuyper se Program van beginsels wat deur SJ du Toit gebruik is, weinig sukses gehad het in Suid-Afrika. President Kruger het wel kontak gehad met Kuyper, maar was geen Kuyperiaan nie.

Na hulle neerlaag in 1902 moes die Afrikaners remobiliseer. Dat Kuyper se idees beskikbaar was en gebruik is, blyk uit hul prioriteite vir rekonsolidering: kerk, opvoeding en sosio-politieke aangeleenthede. Tipies van hul metode was om te begin met goed geformuleerde beginsels. Schutte lei egter af dat dit nie die Neo-Calviniste was nie, maar die Volksnasionaliste wat die botoon gevoer het in die dertiger-en veertigerjare. Dit was nié JD du Toit en die "Doppers" nie, maar Eerste Minister Hertzog ('n agnostikus) en DF Malan (wat teologie in Utrecht gestudeer het en definitief nie 'n volgeling van Kuyper was nie) wat met die Volksnasionaliste die loop van sake bepaal het (Schutte, 1988:192, 194).

In aansluiting by Schutte kan nog twee sake genoem word. Eerstens is dit tipies van apartheidsideologie dat daar ' $n$ volkskerk sal bestaan. Die bepaling van die provinsiale sinodes van die Nederduits Gereformeerde Kerk dat hulle eksklusief blanke kerke is (wat intussen verval het), lewer 
getuienis hiervan. Kuyper, daarenteen, was gekant teen die gedagte van 'n volkskerk en het leiding gegee in hierdie verband (Schutte, 1986:198).

'n Tweede saak is dat daar reuse verskille was tussen politieke partye in Nederland en hier. Die Kuyperiaanse Christelik-nasionale politieke partye en organisasies in Holland, was veel meer eksklusief (meer konfessioneel) as die partye in Suid-Afrika. Anti-revolusionère politiek en Afrikanernasionalisme verskil hemelsbreed as gevolg van die verskil in sosiale konteks.

\section{PJ STRAUSS OOR KUYPER SE VOLKSIDEE}

In 'n dieptestudie dui PJ Strauss (1984:89/91) aan dat Kuyper se idees oor die volk van 1869 (Eenvormigheid de vloek van het moderne leven) tot 1916 (Anti-revolutionaire Staatkunde) dieselfde gebly het.

Kuyper se uitgangspunt was die organiese aard van die samelewing. Binne die geheel van die samelewing is die gesin die primêre "orgaan". Hierdeur groei die gees van die volk. In 1869 het hy skerp gereageer teen die idee dat die eenheid van 'n volk ander volke moet uitsluit. Die doel moet altyd wees: eenheid in veelheid. Eenheid in die koninkryk van God sluit nie veelheid uit nie, maar skakel dit in vir 'n hoer ideaal.

In twee van Kuyper se geskrifte, naamlik sy Planciusrede (Amsterdam. 11/3/1884) en De crisis in Zuid-Afrika (1900), vind mens spore van rassisme of dan kulturele chauvinisme. In eersgenoemde moedig hy die Transvalers aan om nie enige valse medemenslikheid teenoor Swartes te openbaar nie, maar om liewer egte Christelike politiek te beoefen deur hulle eventueel op te hef tot gelykheid. In sy geleentheidsbrosjure oor die oorlogskrisis in Suid-Afrika, protesteer hy teen die Britse politiek. Hy verwys hierin na Swartes as 'n laer ras. Om hulle as gelyke te behandel in die gesin, gemeenskap en politiek sou absurd wees. Hy toon selfs begrip vir die Boere se verset teen bloedvermenging!

Dit moet duidelik wees dat Kuyper in hierdie twee werke die noodlydende Boere wou bemoedig. Die ware Kuyper slaan 'n ander toon aan in De Gemeene Gratie, Antirevolutionare Staatkunde en die Stonelesings .

Volgens Strauss sien Kuyper die volk as 'n skeppingsordening met 'n biologiese basis. 'n Mens is voorbestem om tot 'n sekere volk te behoort. Die gesinslewe lei tot die wese van 'n volk. Die invloed van die Duitse Idealisme blyk daaruit dat Kuyper verwys na die "gees" van 'n volk.

\section{KUYPER SE EINTLIKE (?) SIENING}

In die Stone-lesings noem Kuyper $(1931: 63 / 4,66 / 7)$ die volk nie 'n skeppingsordening nie. Hy beklemtoon hierin die positiewe gevolge van diversiteit. Vir die algemene ontwikkeling van die menslike geslag is "commingling of blood" 'n moet. Isolasie lei tot stagnasie terwyl bloedvermenging lei tot 'n hoer ontwikkelingspeil.

Kuyper (1931:68/9) eien die eer vir die Calvinisme toe dat dit die volke in staat gestel het om mondig te word:

Thus far every forward movement had gone forth from the authorities in State.

Church or Science. and from thence had descended to the people. In Calvinism 
on the other hand, the peoples themselves stand out in their broad ranks and from a spontaneity of their own, press forward to a higher form of social life and conditions. Calvinism had its rise with the people.

In sy lesing oor "Calvinism and politics" noem Kuyper nie die volk nie. Hy handel oor die staat - die staat wat nie 'n skeppingsordening is nie, maar 'n produk van die sondeval.

For. indeed, without sin there would have been neither magistrate nor stateorder: but political life, in its entirety would have envolved itself, after a patriarchal fashion, from the life of the family. (Kuyper. 1931:128.)

Die idee van een mensheid uit een bloed lei hom tot die gevolgtrekking dat sou daar geen sonde wees nie, sou daar nie verskillende regerings gewees het nie, maar slegs éen staat wat die hele mensheid sou insluit (Kuyper, 1931:127).

Kuyper (1931 : 149) het egter geen ongekwalifiseerde gelykheid van alle mense geleer nie.

There is no equality of person. There are weak and narrow-minded persons, with no broader expanse of wings than a common sparrow; but there are also broad, imposing characters, with the wing-stroke of an eagle

Ook het Kuyper (1931:167) groot waarde geheg aan die vryheid van die individuele gewete wat slegs aan God ondergeskik is.

This need of the personal liberty of conscience, however, does not immediately assert itself. It does not express itself with emphasis in the child, but only in the mature man: and in the same way it mostly slumbers among undeveloped peoples, and is irresistible only among highly developed nations.

In sy Antirevolutionaire Staatkunde I (1916) het Kuyper 'n hoofstuk oor die volk as "organiese eenheid". Nie alleen maak individue en gesinne 'n volk uit nie, maar die verskillende volkere is ook lede van die een liggaam van die mensheid (Kuyper, 1931:145). 'n Staat kan tot niet gaan terwyl 'n volk voortbestaan. Die organiese karakter van die gemeenskap word nie geopenbaar in die staat nie, maar in die volk (Kuyper, 1931:146). Vergeleke by die volk is die staat van sekondêre belang. Ten opsigte van rasse is hy nie seker of die verskille beperk moet word tot die fisiese sy van die menswees nie - omdat liggaam en siel eén is (Kuyper, 1931:165. 155). Sosiale faktore dra by tot verskille binne dieselfde ras. Daar is definitiewe verskille tussen volkere. Hy vergelyk die Chinese en die Negers. Hy neem in hierdie konteks ook weer die tema op van die positiewe effek van huwelike tussen individue van verskillende volke (Kuyper, 1931:156/9). Van groot belang ag hy die rol van taal in die lewe van 'n volk. Die staat behoort die onafhanklikheid en die individuele karakter van 'n volk in beskerming te neem en die unieke karakter van 'n volk word bepaal deur sy taal, sy eiesoortige lewensbeskouing en sy individuele denkruimte (Kuyper, 1931:159/160).

In Pro Rege (1912) wat handel oor die koningskap van Christus, konstateer hy dat die staat nie van die begin af bestaan nie. Die gesinslewe het daaraan vooraf gegaan (Kuyper, 1912:227/8). Hy verwys na artikel 36 van die Belgiese Konfessie oor die verhouding sonde/staat. Die staat het noodsaaklik geword weens die sonde. Die gedagte van 'n preeksistente idee van die staat as deel van die menslike natuur soos deur 
die middel-agtiende-eeuse filosowe voorgedra, verwerp hy omdat dit geen Bybelse begronding het nie (Kuyper, 1912:229). Hy noem die staat 'n meganiese of operatiewe verband teenoor die organiese eenheid van die mensheid. Die eenheid van die mensegeslag is egter vernietig deur die sonde. Die staat as operatiewe verband moet hierdie gedisintegreerde mensheid weer verenig. In die hemel sal hierdie organiese eenheid herstel wees en sal die mistieke liggaam weer 'n organiese eenheid wees (Kuyper, 1912:231). Die ontstaan van verskillende volke word gesien as 'n resultaat van die spraakverwarring by Babel waar 'n Volksgeist aan die werk was.

Wat is die volk dan? Vir Kuyper is dit 'n groep mense met dieselfde oorsprong wat saamleef.

Sedert die tyd van Konstantyn die Grote was die volkskerk 'n verskynsel in omtrent elke land. Die volkskerk wil die hele nasie insluit om te dien as waarborg vir nasionale eenheid. Calvinistiese lande het egter, in teenstelling hiermee, ook ander kerke op hul grondgebied toegelaat (Kuyper, 1902b:262/3).

'n Christelike land, staat en volk is moontlik deur die algemene genade. In so 'n land kan die kerk optree as instrument van besondere genade. So word die lewe van die volk opgehef. Die Christelike invloed dra noodwendig ' $n$ konfessionele karakter. In hierdie verband word die konfessie nie beskou as ' $n$ uitwendige band nie, maar in verband met die beginsels wat die aard van die belydenis bepaal (Kuyper, 1902b:667).

Onder die hoof "Christelike beskawing" bring Kuyper (1902b:688/9) ook hier die verskil in ontwikkelingspeil by verskillende volkere ter sprake. As kontinent het Afrika vir hom die laagste ontwikkelingspeil. Tipies van Afrika is kannibalisme, die afwesigheid van literatuur, mense wat in die openbaar kaal loop en in hutte bly! Na elke oes moor en plunder hulle ander stamme! Hulle ontwikkeling kon geen bydrae na buite lewer nie!

Slegs in De Gemeene Gratie III word die ordinansies van God in verband gebring met volk en regering. Dit is deur 'n verordening van God, sê Kuyper (1902b:87), dat regering en volk onderlinge verantwoordelikhede het. Staatsabsolutisme is teen die wil van God - net soos wat opstand teen die owerheid dit is. Die Nederlandse voorvaders het God se absolute soewereiniteit erken en beide koning en volk was aan God se gesag onderworpe. Wanneer die owerheid teen God se verordening in sy mag misbruik, is verset 'n plig (Kuyper, 1902(b):87). In hierdie verband word skeppingsordening nie gebruik ten opsigte van die volk as volk nie, maar van die staat as owerheid en onderdane. Dit word verduidelik aan die hand van die verset van Willem van Oranje teen Spanje.

Kuyper (1902b:91) verwys hierin net een keer na die volk of nasie as skeppingsordening: Die volk wat hom bedien van geslagte, stam van die skepping af, want met die skepping is bepaal dat daar gesinne en geslagte sou wees. Verskillende belange het tot verskillende sosiale sfere gelei, elk met sy eie gesag of soewereiniteit. Die owerheid het die taak 
om met eerbiediging van hul eie aard, die regte van verskillende lewensfere tot mekaar af te grens.

\section{GEVOLGTREKKING}

Uit die stof wat hier uit Kuyper se werk geselekteer is, is dit duidelik dat minstens onsekerheid bestaan oor wat hy presies gedink het van die volk as skeppingsordening. Kuyper was klaarblyklik meer geïnteresseerd in die struktuur van kerk, staat en gesin. Een ding is seker: Kuyper het geen eksklusivistiese volksidee voorgedra nie. Hy leer ook geen volkskerk nie. Hy was wel bewus van die probleme in verband met kulturele diversiteit en die feit dat taal en kultuur so 'n groot rol speel in die lewe van 'n volk.

Afrikaner-teologie het van Kuyper se terminologie gebruik gemaak en dit verder gevoer as wat hy ooit sou doen. Kuyper het nooit apartheid gepropageer nie, maar opheffing. Hy het nooit nodig gehad om te skryf oor die probleem van meer as een volk uit verskillende wêrelde op dieselfde territorium nie. Hy het staatsabsolutisme en die stemloosheid van die massa nóbit gesanksioneer nie.

Brown (in Kleynhans 1989:31) merk op:

Dat sieninge van Kuyper aangewend is om 'n staatkundige bestel vir SA op te stel of 'n regeringsbeleid te fundeer, is sekerlik so. Maar om dit verantwoordelik te hou vir "apartheid" is vergesogd. Daar sal nog ingevra moet word op die invloed van die 'common sense' realisme so eie aan die Skotse teologie in dié verband.

Enkele gevolgtrekkings kan verder gemaak word:

- 'n Totale herwaardering van Kuyper as sleutelfiguur in ons Reformatoriese erfenis moes reeds gedoen gewees het;

- Die volksideologie in die kerklike lewe van die Afrikaner durf nie sitosito aan Kuyper toegeskryf word nie. Soos Schutte aangedui het, is elke nasionalisme (ideologies of nie) 'n uiters ingewikkelde histories-gegroeide, sosiokulturele aangeleentheid;

- Dat daar 'n ordening van God vir volk-wees bestaan, het te doen met 'n kulturele stempel wat oorwegend is vir 'n groep mense van 'n sekere territorium;

- Ten spyte van bloedbande tussen volksgenote is volke nooit bioties eksklusief nie en bloed nie kwalifiserend vir volk-wees nie;

- Die vyande wat deur 'n volksideologie aan die betrokke volk voorgehou word, openbaar dikwels meer daarvan as die geskiedenis van idees;

- Volksideologie kan alleen oorwin word as die volk teruggedwing word tot sy ware skeppingsmatige plek binne die koninkryk van God. Dan staan die koninkryk en staat en kerk en gesin en kuns nie in diens van die volk nie. Ook nie die teologie nie.

\section{BRONNELYS}

Botha, AJ. 1984. Die evolusie van 'n volksteologie. Bellville: Universiteit Wes-Kaapland. Botha, ME. 1982. Christelik-Nasionaal. Outentieke ideologiee of gesekulariseerde nasionalisme? Potchefstroom: Instituut Reformatoriese Studies. PU vir CHO.

De Gruchy. JW. 1982. The Church Struggle in South Africa Grand Rapids, Michigan: Eerdmans. 
De Gruchy, JW. 1984. Bonhoeffer and South Africa. Grand Rapids, Michigan: Eerdmans.

Evangelical Witness in South Africa. 1986. Dobsonville: Concerned Evangelicals.

Kerk en Samelewing. 1986. Bloemfontein: Algemene Sinode van die Nederduits Gereformeerde Kerk.

Kleynhans, EPJ, (red.). 1989. Abraham Kuyper na 150 jaar. Bloemfontein: Pro Christo - Publikasies. (UV Teologiese Studies no. 2.)

Kuyper, A. 1931. Calvinism: Six Stone-Lectures. Michigan: The Reformed Press, s.a. Lectures on Calvinism. Grand Rapids: Associated Publishers and Authors Inc. 1902. (a, b, c) De Gemeene Gratie I, II, III. Kampen: Kok.

1912. Pro Rege III. Kampen: Kok.

1880. Souvereiniteit in eigen kring. Kampen: Kok.

1916. Antirevolutionaire staatkunde I. Kampen: Kok.

Langley, MR. 1988. A sketch of Abraham Kuyper's life. RES Theological Forum, Vol. XVI, no. $2,4 / 8$.

Ras, volk en nasie. 1975. Kaapstad: N.G. Kerk-Uitgewers. (Algemene Sinode van die Nederduits Gereformeerde Kerk)

RES Testimony on Human Rights. 1983. Grand Rapids. Michigan: RES

Schutte, GJ. 1986. Nederland en de Afrikaner, adhesie en aversie. Franeker: Wever.

Skillen. JW, 1988. Kuyper was on time and ahead of his time. RES Theological Forum. Vol. XVI, no. 2.

Smit. JH. 1989. Kerk en Samelewing oor geregtigheid en menseregte. (In Van der Walt. BJ en andere. Kommentaar op Kerk en Samelewing. Potchefstroom: Potchefstroomse Universiteit vir Christelike Hoer Onderwys. p 56-75.)

Strauss, PJ. 1984. Kuyper, ras, volk en Suid-Afrika. Tydskrif vir Christelike Wetenskap. le kwartaal.

Wolterstorff, N. 1983. Until Justice and Peace Embrace. Grand Rapids. Michigan: Eerdmans. 